\title{
Gandang Tasa: The King of Processional Music in Minangkabau
}

\author{
Yunaidi Asril ${ }^{*}$ \\ Karawitan Department, Faculty of Performing Arts Institut Seni Indonesia Padangpanjang
}

\begin{abstract}
Gandang tasa is a genre of traditional percussion music that continues to dominate various traditional and religious processions in Minangkabau, West Sumatra. Its musical power rests only on the performance of the rhythmic patterns of the gendang and tasa, which are played simultaneously and in an impulsive manner. The music is loud, energetic, and played in an open arena, either in the form of a procession or in an outdoor performance. The goal of this article is to discuss the dominant role of gandang tasa in various traditional and religious ritual processions in the Minangkabau community. The research method is a case study which focuses on the presence of gandang tasa in various ritual processions. The research results show that the loud, energetic character of the music, and the musical power of the rhythmic patterns played by the gandang tasa have led this music to dominate traditional and religious ritual processions in Minangkabau.
\end{abstract}

Keywords: gandang tasa, king of processional music, energetic, Minangkabau

DOI: $10.7176 / \mathrm{ADS} / 83-02$

Publication date:July $31^{\text {st }} 2020$

\section{Introduction}

The people of Minangkabau have a variety of traditional music that is used in different traditional and religious ritual processions. Some ensembles, such as talempong, gandang oguang, gandang sarunai, gamad, katumbak, and gandang katipik, are used only for traditional ritual processions. Other ensembles are used solely for (Islamic) religious rituals; these include rabano, pano, and other similar genres using the frame drum. However, there are also a number of musical ensembles that are used for both traditional and religious rituals, and gandang tasa is one such ensemble.

This traditional musical ensemble is a relatively small group, consisting usually of 6 to 10 instruments. This music is generally used in a procession to bring excitement to a ritual. Socially speaking, its function is merely to provide support and entertainment. This means that the presence of this music is not an absolute requirement. Asril writes that:

"Traditional music in the Minangkabau culture is integrated with various life contexts that are social, such as entertainment, ceremonial, and ritual. The form of this integration may be flexible or strict. Flexible means that the presence of the music is not an absolute requirement but it has a very important effect on the ceremony or activity in which it is used. Here, music only plays the role of bringing excitement to the ceremony and serves only as entertainment." (Asril, 2015: 68).

The types of traditional music that have the function described by Asril above, specifically for use in processions, are talempong, gandang oguang, gandang sarunai, gamad, katumbak, gandang katipik, rabano, pano, and several other genres of frame drum music. There are, however, exceptions, in forms where the musical integration is much stricter in nature. When the music is integrated strictly in a ritual, it becomes an important part of the ritual that cannot be omitted. This means that the ritual depends strongly on the music to execute and bring excitement to the ritual (Asril, 2015: 68). The music referred to here is gandang tasa. The function of gandang tasa when it is closely integrated in a ritual event can be seen in the Tabuik ritual in the town of Pariaman and the mauluik ritual in Sicincin. Both are religious rituals. In addition, gandang tasa is used in various other traditional rituals in the Minangkabau community.

Gandang tasa is a relatively small ensemble of rhythmic percussion music. It consists of between 6 and 10 gendang, or large double-headed drums (with a diameter of $48-52 \mathrm{~cm}$ ) and one tasa, or single-headed drum, which is smaller than the gendang (with a diameter of $30-35 \mathrm{~cm}$ ). This music does not use any melody instruments. According to Asril: "The pieces played are constructed from the interlocking rhythmic patterns of the gendang and tasa. There are no instruments that play a melody. The power of the music rests only in the interplay of the rhythmic patterns. It is as though the arrangement of these rhythmic patterns transforms into a melody...." (Asril, 2015: 70).

The use of different types of music in various processions in Minangkabau has a strong influence on their existence in these rituals and in the community. The dominance of a musical ensemble is determined largely by its function in various rituals. Why has gandang tasa become a musical ensemble that is used in both traditional and religious rituals in a way that is so closely integrated in the ritual? This is the phenomenon that will be discussed here, with specific focus on the dominance of gandang tasa in ritual processions, which has led to it being labeled the 'king' of processional music in Minangkabau. 


\section{Method}

The method used in this research is a qualitative method that focuses on a case study of the function of gandang tasa in various ritual processions in a traditional and religious context in Minangkabau. A field study was the main priority for collecting data related to the function of gandang tasa in a ritual context. The observation of various performances of gandang tasa in different ritual contexts was limited to mauluik rituals, bridal parades, and musical accompaniment for the Galombang dance, in order to look at the dominance of gandang tasa in each of these ritual contexts. To reinforce the data about the role of gandang tasa in ritual processions, interviews were also conducted with ritual performers and gandang tasa players, along with a number of other informants who were considered to hold important information. In addition, observations were also carried out of other musical ensembles, such as talempong used in traditional ritual processions and rabano used in religious ritual processions. The purpose of this was to compare the function of these ensembles with gandang tasa, in order to obtain data to support the dominance of gandang tasa in ritual processions.

\section{Results and Discussion}

The traditional music ensembles that are often used in various traditional and religious ritual processions in the Minangkabau community are either ensembles of percussion instruments or a combination of melodic and percussion instruments. The genre of percussion music can be divided into two categories, namely melodic percussion and rhythmic percussion. The melodic percussion genre has a number of variants. In general, the melodic percussion genre refers to music ensembles that use 5-7 talempong instruments, or small gongs (with a diameter of 15-17 cm), which play the melody, and 1-2 aguang, or larger gongs (with a diameter of $25-30 \mathrm{~cm}$ ), which provide support and regulate the rhythms. Other versions use a combination of talempong, aguang, gendang and sarunai (a traditional Minangkabau wind instrument). A simpler version uses only talempong instruments. All these musical ensembles are used in various traditional ritual processions. As explained by Hanefi, et al., (2004), talempong ensembles are often used for traditional ritual processions such as parading a newly appointed local leader (panghulu). The panghulu is paraded around the village in a procession accompanied by a talempong ensemble to announce to the local community that a new leader has been appointed.

All the different kinds of talempong ensembles are small groups. The character of the music is animated, joyful, and spirited, with short, repetitive melodies that are formed by the interlocking patterns played by the talempong musicians. The music is highly appropriate for enlivening various traditional ritual processions. However, its sound carries only limited reverberation so the effect produced is not intended to evoke passion or excitement in the ritual.

The rhythmic percussion genre includes music ensembles from various percussion genres, such as rabano, pano, and gandang tasa. The instruments of pano and rabano ensembles, and other similar variants using frame drums, play rhythmic patterns that differ from one instrument to another. Apart from the frame drums, these ensembles are also supported by vocal melodies influenced by a blend of Islamic and Minangkabau culture. This music is characterized by its lively, joyful sound, produced by the combination of rhythmic patterns played by the rabano, supported by the vocal melodies. In general, this music is played for religious processions, such as inaugurations involving a parade of children who have successfully completed their studies learning to read the Qur'an, Islamic festivals such as the birth of the Prophet Muhammad, and Islamic New Year celebrations. All of these musical ensembles are small groups which play music with an Islamic character at a moderate tempo. This kind of music is played frequently by the Minangkabau community living in the Darek region, or the highland and hinterland region of Minangkabau.

Another genre of rhythmic percussion music is gandang tasa. Gandang tasa is found widely in the Pesisir region of Minangkabau (in the lowland area along the west coast), in particular in the district of Padang Pariaman and the town of Pariaman. These two areas are the main bases where gandang tasa has grown and developed. In addition, gandang tasa is also found in Maninjau, a sub-district of Agam district, which is also considered the base for the development of Maninjau-style gandang tasa. The character of gandang tasa music is loud and energetic, and its performance tends to be attractive, which is the reason why this music continues to dominate performances in processions and outdoor arenas (Asril, 2015: 70).

\subsection{Contexts of Gandang Tasa Processions}

Gandang tasa is performed in various ceremonies and social events. These include wedding ceremonies, bridal parades, celebrations to mark the birth of the Prophet Muhammad, alek nagari (traditional village art festivals), Tabuik ceremonies, and as accompaniment to performances of the Galombang dance. In all of these contexts, gandang tasa is more often used for rituals that are in the form of processions or parades. Below is a description of the various ritual contexts involving gandang tasa.

\subsubsection{Wedding ceremonies and bridal parades}

In the Minangkabau community, wedding ceremonies usually take place over two days. The first day is for the marriage ceremony and includes a small-scale party for the local community, while the second day is the peak of 
the celebrations with a party attended by guests from various other areas. Members of the Minangkabau community who most frequently use gandang tasa in their wedding ceremonies are the people of Pariaman (in Padang Pariaman district and Pariaman town) as well as a small number of people in the district of Agam, especially the Maninjau community. The Pariaman people use gandang tasa for both days of their wedding celebrations, as entertainment and in the bridal parade. In the context of entertainment, the gandang tasa performance is held on the first day and also as the climax of the celebrations, when it is played from midday until late night, either in the home of the person holding the wedding or at the location of the festivities.

On the day of the main festivities, there is one important event that is an integral part of the Minangkabau wedding tradition, namely the bridal parade. The bridal parade may take place in one of two ways: either parading the bridegroom from his house to the house of the bride, or parading both the bride and bridegroom from the bride's house to the bridegroom's house. The gandang tasa is played throughout both forms of the bridal procession, along the road that the procession passes through on the way to the bride or bridegroom's house. The loud sound and joyful, energetic character of the gandang tasa music, together with the lively expressions of the players, bring the procession to life. The pulsating sounds produced by the accumulation of all the gendang and tasa instruments can be heard up to $1 \mathrm{~km}$ away during the day and up to $2-3 \mathrm{~km}$ at night, especially in rural areas. The combination of loud, energetic, joyful sounds are what give gandang tasa its power and give the music its masculine character. The pieces played during a wedding party include: Matam Panjang, Oyak Tabuik, Matam Pondok Duo, Matam Turiah Lasuang, Alihan Duo Baleh, Alihan Anam, Kudo Manyipak, Siontong Tabang, Kureta Mandaki, Oyak Ambacang, Katidiang Sompong, Atam, Riak Danau and so on.

In some areas of Minangkabau, various kinds of talempong ensemble are used instead of gandang tasa for bridal processions. However, the power and effect of the music of these talempong ensembles is not as strong, and the music tends to have a more 'feminine' character. Likewise, katumbak ensembles - which play an acculturation of Minangkabau, Melayu, Indian, and Western music - are also used in bridal processions in Pariaman (Asril Muchtar, 2008: 128), but nowadays this is extremely rare, although it is in fact an attractive ensemble to be used in a procession because of its repertoire of pieces that are suitable for this kind of situation. For example, its lively dance music which often tempts people in the procession to dance as they walk. It is thought that katumbak music is rarely used for bridal processions today because its music has experienced a decline in popularity so there are not many groups left that continue to perform.

\subsubsection{Ceremony to Commemorate the Birth of the Prophet Muhammad (Maulid Nabi)}

The performance of gandang tasa in the ritual to commemorate the birth of the Prophet Muhammad is essentially just to create a livelier atmosphere. In this Maulid Nabi ceremony more priority is given to performing music with an Islamic nuance and a religious character, including dhikr, salawat talam or salawat dulang. The gandang tasa does not play an important role and in many areas it is not even played. However, in some villages, or nagari, in the Pariaman district, gandang tasa is an important part of this ceremony and is used during the procession to carry jamba (large amounts of food) and money from a particular hamlet to the mosque. Villages that continue to use gandang tasa for this procession include Sicincin, Parit Malintang, Lubuk Pandan, and Sungai Asam. In these villages, the people in the procession carry money that is fastened to tree branches, and various other attributes created to look like animals, vehicles (cars, aeroplanes), traditional Minangkabau houses, human figures, gadgets, along with model imitations of various other objects. This collection of items carried in the procession is known as bungo lado and referred to by some as tabuik (see Febrina, 2012; Asril, et al., 2018).

According to Maijar, bungo lado is the term used to refer to the tree branches that are decorated with money made to look like leaves. This money is collected from donations by the local community (Maijar, 2018: 159). The term bungo lado refers specifically to the tree branches that the money is attached to, as described by Maijar, but because over time the original form of the bungo lado has developed to include other objects, and it is swung around and pounded to the ground (dihoyak) during the parade, similar to the Tabuik ritual in Pariaman town, it is also sometimes now known as tabuik. In Sicincin, for example, people prefer to call it tabuik rather than bungo lado. To the people in Pariaman, bungo lado refers to a form of mutual cooperation (gotong royong) or working together in a spiritual activity or to build a place of worship. Bungo lado is the collective contribution of the local people used for building a mosque or holding a religious event (Maijar, 2018: 162).

The parade of bungo lado that is accompanied by the gandang tasa takes different forms in different places. Villages such as Parit Malintang, Lubuk Pandan, Sungai Asam, Sungai Pasak, Koto Marapak, and several others use gandang tasa while the procession is taking place for the purpose of enlivening the atmosphere of the celebration. Those participating in the procession and the spectators along the route of the procession show expressions of joy and appear to revel in the lively atmosphere. The loud, pulsating sound of the gendang that play interlocking rhythms enhances the festive mood of the procession.

In other villages, such as Sicincin, the procession of the bungo lado - which they commonly refer to as tabuik - is performed in a completely different way. The people of Sicincin use the gandang tasa ensemble in the procession not only to make the atmosphere more lively and enjoyable. They also use it to arouse a spirit of excitement, sometimes triggering violent emotions, because there is an element of 'competition' in parading the 
tabuik between one hamlet and another inside the village of Sicincin. Each group in the procession will do their best to create as much excitement as possible, so that they receive a lively response by those who have come to watch. To achieve this lively response, it is common for the participants in the procession to cheer, sway, and dance in time to the rhythms of the gandang tasa that are played at a high volume.

It is also common for such events to take place in Sicincin during the mauluik ritual, in which the gandang tasa ensemble plays a strong role in creating a festive atmosphere for the process. Febrina writes:

"Each year, the Sicincin community performs the mauluik ritual in a different way. Every two years the mauluik ritual is held on a large scale, involving all the members of the community. This biennial mauluik ritual is a special event for the Sicincin community and includes a procession with a tabuik, accompanied by the music of a gandang tasa ensemble, until some people enter into a trance." (Febrina, 2012: 68-70).

The gandang tasa is played continuously until the procession reaches the courtyard of the mosque, and the tempo of the music gradually becomes faster and faster until some of those in the procession lose consciousness. This statement by Febrina is also confirmed by Asril, et al., (2018: 16), who write:

"The music of the gandang tasa plays an important role in developing an atmosphere of excitement and creating a spirit of togetherness, and without the presence of the gandang tasa, the mauluik ritual would not be as special. However, in addition to this, the gandang tasa also has the ability to create an atmosphere that is ironic and frenzied, in which there is a loss of control and the true sense of mauluik is no longer present."

The piece played during the procession is called Oyak Tabuik. Romy Junaidi Sidi Brahim, a prominent figure in the Sicincin community who was the main gandang tasa player during his younger years for every mauluik ritual, stated: "The piece we play is called Oyak Tabuik, it is the same as the music played in the Tabuik ritual in the town of Pariaman (Asril et al., 2018: 20). However, according to Febrina, the piece played during the mauluik procession is not the same as the Oyak Tabuik piece that is played in the Tabuik ceremony in Pariaman (Febrina, 2012: 60). In fact, the piece that Brahim is referring to as Oyak Tabuik is actually a piece called Sosoh, or the piece that is always played together with Oyak Tabuik but is positioned at the end. This piece has a fast tempo and loud dynamics, making it highly suitable for arousing the excitement of participants in the procession.

3.1.3 Music for the Galombang dance

Galombang is the name of a dance that is performed to welcome guests. There are two kinds of Galombang dance used in Minangkabau, namely the traditional Galombang dance and a modern creation. The traditional Galombang dance is usually performed in traditional ceremonial contexts while the modern creation of Galombang, which is more commonly known as Pasambahan ('offering') is used to welcome guests outside a traditional context, such as in government ceremonies, private events, or ceremonial occasions in other organizations. As Asriati explains: "The Pasambahan dance is currently very popular in West Sumatra, especially in the town of Padang. This dance is often presented on ceremonial occasions such as the official opening of government events and other formal occasions" (Asriati, 2012: 146). The music used is a combination (percussion and melodic) of several traditional Minangkabau instruments that has been specially arranged. However, the music also includes a set of gandang tasa to strengthen the dynamics, reinforce the rhythms, and enhance the lively mood.

The traditional Galombang dance in Minangkabau can be found in a number of variants, each with its own unique local characteristics. For example, in Koto Kaciak Kabupaten Lima Puluh Kota, the Galombang dance uses music performed by bansi (traditional wind instrument), gendang (small double-headed drum), talempong, and tambourine (Nurfadhilah, et al., 2018: 16). In other areas in the Darek region of Minangkabau, the musical accompaniment for the Galombang dance uses talempong, aguang, gendang, and sarunai (traditional wind instrument).

Unlike the tradition in these two areas, performance of the Galombang dance in the Pesisir region of Minangkabau, specifically in the district of Padang Pariaman and Pariaman town, is based on silek (the martial art of silat). The dancers are male silat artists and the dance is performed by two groups of dancers who face each other as they perform. For this reason, the the musical accompaniment needs to be more energetic and 'masculine' in nature to build up the emotion and spirit of the dancers. The music used here is gandang tasa. The Galombang dance is used to welcome honorary guests in a traditional context, such as a ceremony to appoint a new rajo (a local aristocrat, a symbolic leader in the concept of Minangkabau tradition in Pariaman), panghulu (leader of a tribe or clan), or other traditional ritual. This dance is performed to welcome the guests of the rajo and panghulu when they arrive. The Galombang dance is a way of honouring the guests, who are usually rajo and panghulu from other villages or nagari. Sometimes, a group of guests also brings its own Galombang dancers. In this case, two groups of Galombang dancers perform at the same time, facing each other while keeping a relatively long distance (about 20-30 meters) at first, then gradually moving closer together until they come face to face with each other. While the dance performance takes place, the gandang tasa is used to play the musical accompaniment. The loud, pulsating sounds of the gendang provide an energy that fills the atmosphere with excitement and intensity. The gandang tasa musicians are teenage boys and young men. However, for the past five years, female players have also begun to play the gandang tasa to accompany performances of the Galombang dance in Pariaman. They 
play gandang tasa just like their male counterparts. An example can be seen in Figure 1 below.

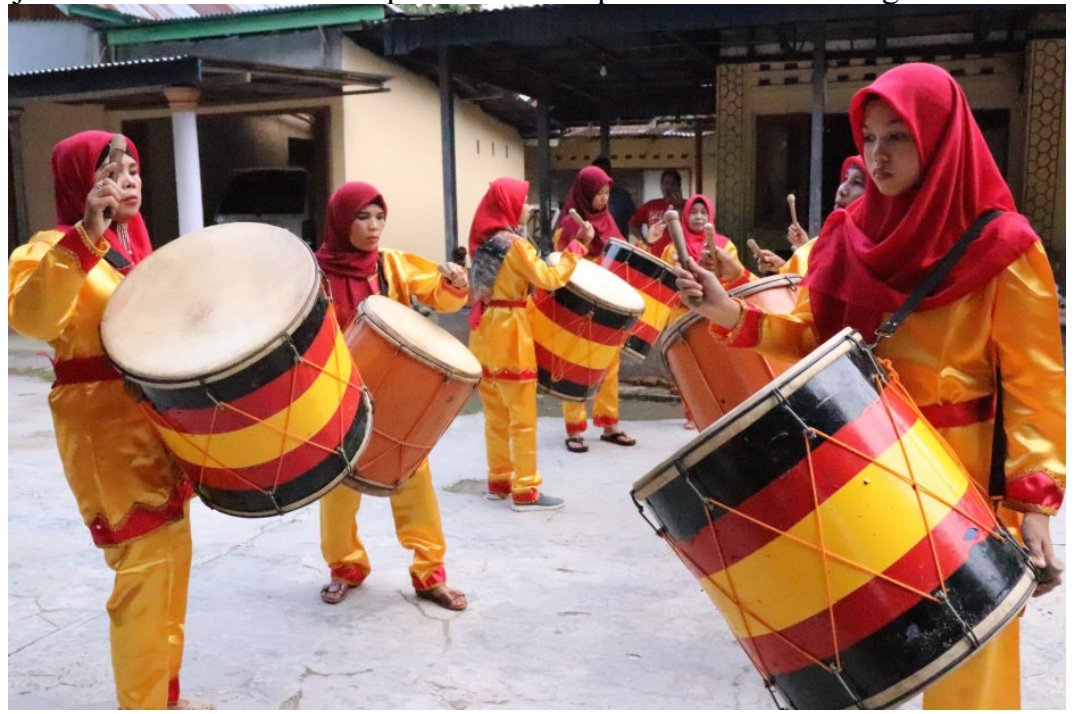

Figure 1. Female gandang tasa players from the Tanjung Pisang group, in Sintuk, Padang Pariaman District (Photo: Asril Muchtar)

Until now, gandang tasa is still used to accompany the Galombang dance in Pariaman. The role of the gandang tasa has not yet been replaced by another traditional Minangkabau musical ensemble such as the talempong ensemble that is commonly used in the Darek region of Minangkabau. It is clear that the gandang tasa plays an important role in firing up the emotion and spirit of the Galombang dancers. If they were not accompanied by the music of gandang tasa, this kind of atmosphere would be impossible to create. The energetic character of gandang tasa music, along with its loud dynamics and 'provocative' rhythmic patterns is able to arouse the emotion and spirit of the dancers.

\subsection{Gandang Tasa as the King of Processional Music}

Based on the description of the various musical ensembles used in processions in a traditional and religious context in Minangkabau, including talempong, aguang and other variants, pano, rabano and other variants, it can be said that each of these ensembles plays only a very specific role, either for a traditional procession or a religious procession. The musical character of all these ensembles is light, cheerful, and suitable for building a mood of joy or reverence, with limited power achieved by the accumulation of sounds of all the instruments. This is different for the gandang tasa ensemble, however, which can be used for processions in both a traditional and religious context. In a religious context, for example to accompany the mauluik procession in a number of nagari in Padang Pariaman district and Pariaman town, gandang tasa is used in processions to parade the bungo lado and tabuik. More specifically, in Sicincin, when parading the tabuik to the mosque, the role of the gandang tasa cannot be replaced by any other musical ensemble that exists in Minangkabau. The musical power of gandang tasa, with its high energy, loud sound and dynamics, fast tempo, and special pieces - Oyak Tabuik or Sosoh - arouses the spirit of the participants in the procession, making them excited, wild, and even causing them to lose control and enter into a trance-like state. The participants move and shout as a natural way to channel their expression and emotions, triggered by the music of the gandang tasa. Asril, et al., (2018: 19-20) write:

"As the groups processing approach the courtyard of the mosque, the beat of the gendang becomes louder and the tempo increases slightly, making the atmosphere livelier. The participants in the procession dance around with their hands raised above their heads. Meanwhile, those carrying the tabuik and other attributes lift them high above their heads and shake them about. All of the participants shout out loud the words hoyak, hoyak, hoyak, which means shake harder and stronger. When they enter the courtyard of the mosque, the tabuik are quickly demolished and their remains discarded by members of the committee because the tabuik act as a trigger to make the atmosphere more 'heated' and frenzied. Next, all the participants move in various directions while dancing and swaying to their heart's content (none of the movements are coordinated), following the beat of the gendang, and the atmosphere begins to get out of control. In only a few moments, some of the participants in the procession who have become deeply engrossed in the events start to fall to the ground, losing consciousness and experiencing convulsions as they enter into a trance."

The mauluik ritual is actually a celebration of the birth of the Prophet Muhammad, which is celebrated by Muslims in Minangkabau with activities that include speeches or lectures about Muhammad's life journey. These stories of the prophet begin with his birth and childhood, telling how he was raised by family after being orphaned as a young child. Further stories tell of the Prophet's behaviour, which Muslims should endeavour to emulate, and 
his teachings about Islam. In addition to these lectures about the Prophet's life, other activities include performances of Islamic music such as barjanji, dikie, ratik, salawat dulang, and salawat talam with texts that are also about the Prophet Muhammad. However, the people of Sicincin celebrate in a different way, by parading a tabuik until some people enter into a trance, which is not relevant to the context of the Prophet Muhammad's behaviour and teachings. What causes people to experience such a situation, leading them to lose control, enter into a trance-like state, or even a full trance? In the same article, Asril et al., write:

"When asked why they could experience a state of trance, or near trance, or flow, the participants of the procession all answered that the sound of the beat and rhythms of the gendang in the gandang tasa ensemble being played at a fast tempo and with a loud volume affected their emotions and caused them to lose control to the point where they lost consciousness." (Asril, et al., 2018: 20).

According to the participants in the procession, it is the pulsating rhythmic patterns of the gandang tasa played at a fast tempo that has a strong effect on their emotions and psychological state, and causes them to experience this loss of control and enter into a state of trance. This is something that could not happen with other musical ensembles such as talempong, aguang, pano, and rabano and other variants, because these ensembles do not have the same energetic, loud, fast musical characteristics. This is why the Sicincin people do not want to use any other ensemble apart from gandang tasa to create the excitement in their ritual.

Another comparison that can be made is with the music used to accompany the Galombang dance. As explained above, in the Darek region of Minangkabau the music used to accompany this dance is one of several variants of talempong, while in the Pesisir region of Minangkabau, specifically in Pariaman, gandang tasa is used instead. The Galombang dance in these two regions is different both in its spirit and in the version performed. In Pariaman, the Galombang dance is based on silat and performed by silat artists, so the expression, content, and spirit of the dance is more aggressive and needs to be supported by energetic percussion music to lift the level of excitement in the dance. This means it is impossible for the Galombang dance in Pariaman to be accompanied by talempong music because it would not provide the necessary support for the expression in the dance. On the contrary, if the Galombang dance in the Darek region was accompanied by gandang tasa, there would be an imbalance between the expression and content of the dance and the highly expressive and percussive musical power. Gandang tasa would dominate the entire Galombang dance performance.

Various new versions of choreography for the Pasambahan dance (new, modern creations of the Galombang dance used to welcome guests) use different musical instruments with new arrangements to play the musical accompaniment for the dance. However, the choreographers are fully aware that a set of gandang tasa must also be included to support the expression and emotion, and build a livelier atmosphere. Since various new versions of the Pasambahan dance have appeared in different towns in the Minangkabau region, this has led to the indirect spread of gandang tasa. As a result, gandang tasa ensembles have begun to appear in districts where this music had not previously developed, leading to its increased dominance. An example of this can be seen in Figure 2 below.

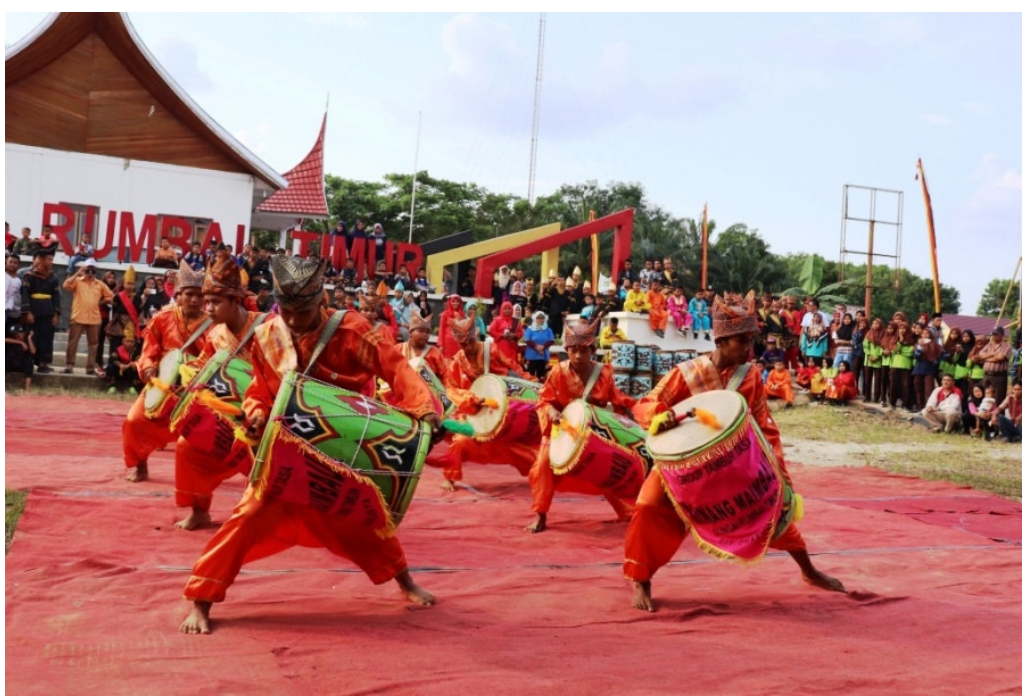

Figure 2. Gandang tasa has become more widespread and is now used in other areas of Minangkabau for ritual and ceremonial performances (Photo: Asril Muchtar)

According to Sloboda (in Djohan, 2005), music can increase the intensity of emotion and it is more accurate if this 'musical emotion' is explained as the mood, experience, and feeling influenced by a catalyst or stimulus that arouses the emotional experience. The emotions described here, in the context of processional music, are emotions of joy and elation. However, these emotions are not sufficient because there is also an even greater achievement, namely for people to become frenzied and take control of the ritual arena as a result of the power of 
the music.

What kind of music can be dominant in a procession? Gilbert Rouget (1985:170) explains that:

"For a variety of reasons the drum is surrounded by much a particular aura that not only the man in the street but also, very often, the man of science readily lends it very special powers. The often explosive, violent, and brutal nature of the sounds it produces, and the frequently dramatic or obsessive use to which it is put, indisputably confer upon the drum a particularly strong emotional impact. Its sound can be a truly aggressive force, and its vibrations can have an almost palpable impact."

This statement is affirmed by Neher, who explains that even when a drum or gendang is played slowly or quietly, it can control the vibrations produced and even cause a person to lose consciousness (Rouget, 1985: 175). If it is played loudly and at a fast tempo such as the gandang tasa playing Oyak Tabuik in the mauluik ritual in Sicincin, the effect will be even greater. All drums, or gendang, in their various shapes and sizes, sounds and noises, have a psychological effect that is able to influence people's hearing and nerves.

In every performance of gandang tasa, the instrument that controls the music is the tasa. The tasa player determines the rhythmic patterns, the accelerations of tempo, and the provocative dynamics, which in turn influence the gendang players. The gendang players accept the 'invitation' of the tasa player to play faster, louder, and with more emotion, raising the energy, spirit, and aggression of the musicians until they seem possessed. This in turn affects the participants in the procession as they respond to the rhythms of the gendang and tasa through their own movements. Hence, it is natural that the gandang tasa, a musical ensemble that consists entirely of drums, has such a strong psychological effect on raising the spirits of the participants in the procession, and this is why it has become the most dominant music, or the king of all processional music in Minangkabau.

\section{Conclusion}

All the different variants of talempong ensembles and pano and rabano ensembles play traditional music that is lively and joyful but tends to have a more 'feminine' character. The accumulation of sounds played by all the instruments in these ensembles has a limited effect on building up the atmosphere in a procession that is accompanied by this music. The situation is quite the opposite, however, when the gandang tasa is used, since this ensemble is characterized by its energetic music, loud sound and dynamics, fast tempo, and 'masculine' character, all of which give it a powerful musical effect on every procession where it is used. In particular, in the context of the mauluik ritual in Sicincin, the role of the gandang tasa cannot be replaced by any other traditional ensemble that is found in Minangkabau. This is also the case with its role in accompanying the Galombang and Pasambahan dances, in which it creates a higher level of energy and lifts the spirits and mood of the performance. The musical power of the percussive music of the gandang tasa has a psychological effect which has made it the king of processional music in Minangkabau.

\section{References}

Asriati, Afifah. (2012), Tari Pasambahan dan Falsafah Minang dalam Perspektif Alim Ulama Kota Padang, in Jurnal Humanus, Vol. XI, no 2, pp. 145-159.

Asril. (2015), Peran Gandang Tasa dalam Pertunjukan Tabuik. In Jurnal Humaniora, Vol. 27, No. 01 February.

Asril., Andar Indra Sastra., and Adjuoktoza Rovylendes. (2018), Performativity of Gandang Tasa in the Mauluik Ritual in Sicincin, Pariaman, West Sumatra. In Arts and Design Studies Journal, Vol 67.

Djohan (2005) Psikologi Musik: Revised Edition. Second Printing. Yogyakarta: Buku Baik.

Febrina, Chyntia. (2012), "Gandang Tambue dalam Upacara Maulud Nabi di Nagari Sicincin, Kecamatan 2 X 11 Enam Lingkung, Kabupaten Padangpariaman, Sumatera Barat.” Thesis, Karawitan Department, Performing Arts Faculty, Institut Seni Indonesia Padangpanjang.

Hanefi, et al. (2004), Talempong Minangkabau: Bahan Ajar Musik dan Tari. Bandung: P4ST UPI.

Maijar, Andri. (2018), Tradisi Bungo Lado Sebagai Representasi Budaya Islam di Kabupaten Padang Pariaman. In Jurnal Ekspresi Seni, Vol. 20, No.2. pp. 153-164.

Muchtar, Asril. 2005. Gandang Tambua: Musik Pembangkit Semangat 'Heroik' dan 'Patriotik' dalam Upacara Tabuik di Pariaman, Sumatra Barat, in Jurnal Panggung STSI Bandung, No. XXXVII.

Muchtar, Asril. (2008), Katumbak MusikTradisi Sinkretik Minangkabau yang Makin Memudar, in Jurnal Aswara, Jilid 3, Bil. 1, pp. 127-142.

Nurfadhilah, Syifa., Nurmalena., and Yarlis. (2018), Tari Galombang Masyarakat Koto Kociak Nagari VII Kecamatan Guguak Kabupaten 50 Kota, in Jurnal Laga-laga, Vol. 4, no.1, pp. 11-21.

Rouget, Gilbert. (1985), Music and Trance: A Theory of the Relations between Music and Possession. Chicago and London: The University of Chicago Press. 